\title{
Perspectives for Development of Regional Passenger Aviation in Poland
}

\author{
Stefan Chabiera \\ Faculty of Management, Wroclaw University of Economics and Business, Wroclaw, Poland
}

\author{
Article history \\ Received: 15-01-2021 \\ Revised: 29-01-2021 \\ Accepted: 12-02-2021 \\ Email: stefan.chabiera@ue.wroc.pl
}

\begin{abstract}
The work presents historical outline and analysis of the current situation in passenger regional aviation in Poland. It provides an overview of the processes functioning in this branch of civil aviation, factors affecting the dynamics of changes and its further development. Moreover, this article indicates the emerging opportunities and threats to the perspectives and an increase in the number of operations and passengers using this type of transport and proposes implementation of the EPATS model in Poland using new technologies.
\end{abstract}

Keywords: Aviation, Regional, Perspectives, EPATS, Poland

\section{Introduction}

Poland is celebrating the 100th anniversary of regaining independence and in the same time the 100th anniversary of Polish aviation. The history of passenger aviation on the area of Poland is also important in this context. Developing an independent transport was of great importance for the independence of Poland both for strategical and economical reasons. One flagship example of that was for sure building a seaport in Gdynia, but the rapid growth of aviation at that time also needs to be noted. After the Second World War, passenger aviation was developing relatively slower, due to the politics of the authorities and geopolitical situation in Europe at that time. However, since the end of Cold War Poland has been making up for the lost time and presently is showing a rapid increase in both number of passenger flights and the number of passengers, as well as a significant improve in the infrastructure over the last thirty years.

Recent decades are characterized with dynamic changes that deserve a closer look. The collapse of a regional airline, Eurolot, in the beginning of the century and low-cost airlines' entrance to the market of domestic aviation gravely affected the situation of the discussed area. In 2018 we could observe high dynamics of growth, even though the market is still not stable, as shown by the example of OLT Express airline, which operated in Poland in 2012 for 4 months only. Carriers' strategies are being permanently modified, which can be exemplified by withdrawal of domestic connections from Warsaw by Ryanair, a big European low-cost carrier, although the connections previously available were very popular with the passengers.
In this context, it is important to review actual and potential chances for development of regional aviation in Poland, as well as analyses the threats and prospects. The necessary changes in strategies of civil aviation administration in Poland should be determined in order to enable a real development of this area of transportation, which will be beneficial for the economy and for the stakeholders.

\section{Polish Regional Passenger Aviation in the Last 100 Years}

First irregular passenger flights in Poland were flights from Warsaw to Paris offered by a French-Romanian aviation company Companie Franco-Romaine de Navigations Aerienne (CFRNA) since 20th September 1920. Regular flights were introduced on 12th April 1921 and continued until 1938. Initially they were operated by three-seat Potez VII and five-seat Potez IX planes and since 1924 by five-seat Berline-Spad planes (Liwinski, 2008).

The first Polish airline, Aero-Targ, was set up in 1921 and it operated for one week only, serving the clients of Poznań International Fair. Aero-Targ offered flights between Poznań, Warsaw and Gdańsk, with a total of 58 flights by Junkers F13 planes and about 400 passengers. The business did not, however, generate the expected revenue, which pointed to a necessity of assigning grants to regional connections in Poland. The fare for the flights from Poznań to Gdańsk was around 6000 Polish marks, which was a competitive price comparing to rail fare of 7884 marks (Liwinski, 2008). Despite the low price, the business was not financially 
beneficial, which might have been due to passengers' fears of using the new means of transport.

The first regular flights in Poland offered by a Polish airway started in September 1922, using planes of Polish Aviation Company Aerolloyd (with German funds) between Warsaw and Gdańsk and between Warsaw and Lwów and later also to Cracow and Vienna. What is important, these connections were subsidized by the Polish government. During 6 years the airline operated 12200 flights with 27500 passengers, as well as mail and goods. In 1925 the company changed its owner and was taken over by Polish capital, so it changed name to Polish Aviation Company Aerolot. New airlines were also set up in different regions of the country, but only one of them, Greater Poland-based Aero covered regular passenger flights between Warsaw and Poznań. In the end of 1928, a fusion took place between Aero, Aerolot and Silesian Aviation Company, which created the LOT Airlines. The company was strongly granted by the government, as its incomes did not cover even $1 / 3$ of its costs. Thanks to government's support, the carrier quickly developed its fleet and the number of connections, both domestic and international (including flights to Lydda in Palestine). In 1939 Polish Airlines LOT employed almost 700 people, including 25 pilots and 37 navigators and onboard mechanics. Its fleet consisted of 18 liners and 8 auxiliary planes (Liwinski, 2008). Nowadays LOT uses almost 70 planes and employs 620 pilots and 1100 crew members, covering in average 350 flights a day on more than 90 routes in 4 continents.

I have described above the beginnings of aviation in Poland, in particular regional aviation, which at the time was of big importance. Even though nowadays Polish airports serve more than 30 million passengers every year and the growth of the aviation sector remains on a high level of more than a dozen per cent (ULC, 2018), regional aviation still requires an indirect or direct support. Connections available from Warsaw in the past, i.e., to Białystok, Częstochowa, Łódź, Koszalin, Olsztyn-Dajtki, or Slupsk, were abandoned due to low financial effectiveness or lack of appropriate infrastructure (Chabiera, 2018). In the 1990 s Eurolot company was set up to provide services in the field of regional aviation but it suspended its business because of worsening financial conditions.

Regional connections realized by low-cost airlines also deserve some attention. Primarily they were not subsidized or covered by support programs based on public funds, which caused the closing of DirectFly airlines in 2007, after only 2 years of providing domestic connections operated by 33-seat planes Saab 340 A, including connections not only from Warsaw.

In 2012 similar connections (but operated by much larger planes) were offered by OLT Express airlines. Even though it was active only for 4 months, it served more than 600000 passengers, while DirectFly served only about 25 000. OLT Express's fall was not caused by financial problems but by blocking its funding by its parent company, Amber Gold, in the first stage of its operation.

New solutions have appeared on the market of regional aviation. Local authorities interested in its development started to subside connections from their local airports. Two examples of that can be connections ordered by authorities managing (or co-managing) airports in Bydgoszcz and in Zielona Góra. Voivodeships started to order promotional actions onboard planes (marketing services for regions), which is also a way of financing connections from airports of low profitability. Also, numerous privileges in airport charges have encouraged airlines like, for example, Ryanair, to start new domestic and regional connections, including ones outside Warsaw. It has to be noted, though, that regional connections are subject to numerous changes. Ryanair used to operate domestic connections from Modlin airport, then moved to Chopin airport in Warsaw. Quite soon yet it cancelled those connections on the end of 2018. It only covered flights between local airports, excluding the capital.

The development and growth of local airports is of importance for the development of this type of aviation. In the last decade, airports in Modlin, Lublin, Szczytno and Radom were opened. Other airports carry out investments to increase their capacity and the quality of service. A shift in the sources of income can also be observed from airport services to accompanying services (parkings, commerce, etc.). This process is caused by a change in cooperation models between airports and airlines, as well as a growing competition in the field. Smaller cities (Opole, Białystok, etc.) also invest in aviation infrastructure. However, the negative example of Radom-Sadków airport (where after half a year passenger connections were stopped) makes them act less ambitiously and less costly.

The examples described above confirm both a potential of growth of local connections market and a continuing instability of the sector. On the one hand, it raises chances for new entities, operating in non-standard business models, but on the other hand, it consists a grave risk for investors interested in those solutions.

\section{Analysis of the Potential and Directions of Development of Regional Aviation in Poland}

There are 65 public use airports (including uncertified) and airports of exclusive use. In the last 10 years, only 15 of them offered regular, publicly available flights. This shows the potential for development of regional aviation within the framework of European Personal Air Transportation System (EPATS), 
established in 2008 by a consortium of 10 entities from 5 countries: Poland (represented by Institute of Aviation), France, the Netherlands, Germany and Hungary (Jaroszewicz and Wróblewski, 2014). According to that model, a business solution ought to be established and implemented, based on the presently existing infrastructure and small planes. It would be necessary as is shown by the example of Polish aviation described above - to create solutions in cooperation with local authorities. Developing a network should lead to complementing - but not to replacing - the existing net of road and rail connections. The potential of such undertaking is shown by the example of OLT Express, which was able to generate a high load factor even on short-distance connections. This conception is not new and it has been covered in literature (Marciszewska, Hoszman 2010; Majka 2015; Mączka 2016), yet no attempts have so far been made to implement it. This was caused, among other factors, by lacks in infrastructure for safety of passenger aviation operations. This includes mostly navigation of take-offs and landings and providing airport services. The development of technology, however, allows to abandon costly ILS systems and to replace them with Global Navigation Satellite System (GNSS), which does not have the precision of highestcategory ILS (Mirosław et al., 2014), but is comparable to first-category ILS, which is used in most airports in Poland. New technologies also allow a remote operation of airports in the model of Remote Tower Services (RTS), developed in Sweden, lowering the cost of small airport operation (Josefsson et al., 2017). Thus, the technological potential for developing EPATS is now much higher than in the time of its establishing. A complex preparation of such implementation is required to enable the success of the idea.

An alternative to financing based on cooperation with local authorities can be selling connections from regional network to airlines lacking sources of clients. In this solution of so-called connecting flights, a big airline purchases local connections which help it load planes travelling on profitable long-distance flights. This requires, of course, a coordination of networks and connection schedules, but it can generate business benefits to both sides of such agreement.

It must be noted that a non-diversified model of income of a regional airline, i.e., financing based only on ticket fees, does not give a potential for business success, as is shown by experiences described before. This is caused by high costs of aviation business and commonly available alternative forms of transport, functioning well on short distances. It is necessary to identify other sources of possible benefit which allow to generate stable income. As was shown above, they can be based on development of the region, leading to orders from local authorities, on profits for large airlines which can gain new passengers for their profitable long-distance flights, but other options are also available. For example, the prestige of passengers travelling by a luxurious means of transport can be connected to additional services (VIP services, business parlors, additional sale onboard, etc.). Another source of income can be creating transport connections for business localized in big distance from large airports, which could operate more effectively if it were connected to international network of air transport.

Regardless of the above considerations on possible business model, a stable growth of number of passengers of regional aviation in Poland can be expected, also in the presently available forms of airline business. Such conclusion can be drawn from prognoses of development of the sector in the coming years, the growth of wealth of people in Poland and the popularity of this form of transport, resulting from a significant reduction of ticket prices and a growing availability of plane connections. Technological development allows to establish networks of connections based on analyses of clients' needs resulting from their activity, which can be effectively observed thanks to social media. Those factors will positively affect the development of aviation based on presently existing airports, but they will not meet whole demand in this respect. It is worth noting that two voivodships do not have their airports.

\section{Conclusion}

As it was shown above, regional aviation has had a significant role in development of regions. Legislative changes and local authorities' determination to obtain air connections led to unlocking the potential of this type of aviation, which resulted in development and enhancement of airport infrastructure and an increase in the number of passengers.

The project of Central Communication Port will also have an impact on further development of aviation, including regional aviation, as it will significantly change the whole sector. It is some kind of analogy to sea port in Gdynia, mentioned in the beginning. However, financial effectiveness of the project is unknown, especially when we take into account the existing and constructed airports in this region of Europe. So far, there are no scientific works analysing the impact of this project on Polish regional aviation.

In the last decades, the most important factor affecting aviation in the world, in Europe and in Poland, were deregulation packages, allowing low-cost airlines enter the market, increasing competition and availability of air transport for the passengers. To implement the EPATS model, described above, further changes in law will be required, allowing airports of exclusive use to operate commercial passenger flights to a higher degree. 
It is thus well-founded to conduct further research leading to a strong basis for implementation of the described solutions and as a consequence to universalization of air transport and enhancement of availability of this form of transport in Polish regions. The research should include law issues, consequences of the planned Central Communication Port (of capacity up to 100 million passengers), as well as a complex business model for airlines operating in the presented solutions.

\section{Ethics}

This article is original and contains unpublished material. The corresponding author confirms that all of the other authors have read and approved the manuscript and no ethical issues involved.

\section{References}

Chabiera, S. (2018). Business Strategies in Polish regional aviation in the last century.

Jaroszewicz, A., \& Wróblewski, W. (2014). System Transportu Małymi Samolotami jako jeden $\mathrm{Z}$ czynników rozwoju regionalnego na przykładzie województwa dolnośląskiego. Logistyka, (3), 2563-2579.

Josefsson, B., Polishchuk, T., Polishchuk, V., \& Schmidt, C. (2017, September). Scheduling air traffic controllers at the remote tower center. In 2017 IEEE/AIAA 36th Digital Avionics Systems Conference (DASC) (pp. 1-10). IEEE.
Liwinski, J. (2008). Transport lotniczy w Polsce w okresie międzywojennym. Lotnictwo, 11, 70-77.

Mączka, M. (2016). Assessement of an alternative mode of transport impact on accessibility in Poland. Prace Instytutu Lotnictwa.

Majka, A. (2015). Analiza możliwości rozwoju systemu transportu samolotami lekkimi w oparciu o sieć lotnisk regionalnych. Logistyka, (3), 3030-3039.

Marciszewska, E., \& Hoszman, A. (2010). System transportu małymi samolotami w Polsce: założenia modelowe i koncepcja funkcjonowania. Zeszyty Naukowe. Problemy Transportu i Logistyki/Uniwersytet Szczeciński, (12), 153-164.

Mirosław, S., Karolina, K., \& Rafał, K. (2014). Analiza porównawcza systemów precyzyjnego lądowania. Prace Naukowe Politechniki Warszawskiej Transport, (102).

ULC. (2018). Statystyki oraz analiza przewozów pasażerskich za trzeci kwartał 2017 roku. Urząd Lotnictwa Cywilnego. https://www.ulc.gov.pl/pl/publikacje/wiadomosci/43 33-statystyki-oraz-analiza-przewozow-pasazerskichza-trzeci-kwartal-2017-roku 